INTERNATIONAL JOURNAL OF RESEARCHES IN BIOSCIENCES, AGRICULTURE \& TECHNOLOGY (c) VISHWASHANTI MULTIPURPOSE SOCIETY (Global Peace Multipurpose Society) R. No. MH-659/13(N) www.vmsindia.org

\title{
COMPARATIVE STUDY ON EFFICIENCY OF ADSORBENTS(ACBCB\&ACFRB)IN REMOVAL OF CHROMIUM(VI)
}

\author{
D. K. Donadkar, K. Gour, P. K. Rahangdale, and Jyoti N Thakre \\ 1. Dept of Chemistry Priyadarshini College of Engineering, Nagpur- 440019 \\ 2. Dept of Chemistry, Priyadarshini J.L. College of Engineering, Nagpur-440009, \\ 3. Dept of Chemistry BhawabhutiMahavidyalaya, Amgaon-441902, \\ 4.St Vincent Palloti College of Enginering\&Technology-440019 \\ Email: kavitapce@gmail.com
}

\begin{abstract}
:
Prsent study describe adsorption of Chromium(VI) ion on activated carbon derived from Ficusracemosabark (ACFRB) and Bombaxceiba bark (ACBCB) as a low cost adsorbent.Chromium is toxic to living being and therefore it is essential to remove it from wastewater. Adsorption capacity of activated carbon derived fromFicusracemosa bark (ACFRB) and Bombaxceiba bark (ACBCB) for $\mathrm{Cr}(\mathrm{VI})$ ion abetment was investigated through batch adsorption experiments. Activated carbon was characterized using techniques like FTIR and SEM.The effects of contact time, $\mathrm{pH}$ and adsorbent dose on the removal of $\mathrm{Cr}(\mathrm{VI})$ have been studied and reported.The maximum adsorption capacity of the adsorbent $\mathrm{ACBCB}$ under study for $\mathrm{Cr}(\mathrm{VI})$ was found to be $96.8 \%$ at optimum $\mathrm{pH} 5$ and 100 minutes as optimum contact time and the percentage removal of $\mathrm{Cr}(\mathrm{VI})$ ions was found to increase with increased adsorbent doses from 1 to $6 \mathrm{gm} / \mathrm{lit}$ and for adsorbent .ACFRB the maximum adsorption capacity wasfound to be $89.5 \%$ at optimum $\mathrm{pH} 5$ and 120 minute asoptimum contact time The percentage removal of $\mathrm{Cr}(\mathrm{VI})$ ions was found to increase with increased adsorbent doses from 1 to $7 \mathrm{gm} /$ lit.
\end{abstract}

KEY WORDS: Ficusracemosabark, Bombaxceiba bark,Adsorption isotherms.

\section{INTRODUCTION:}

Environmental pollution is currently one of the most important issue facing by humanity.In the past few years environmental pollution is increased exponentially and reached alarming levels in terms of its effects on living creatures.[1,2] However environment become polluted not only by rapid industrialization, deforestation and unplanned urbanization, but also some natural phenomenon of anthropogenic activities such weathering of rock and volcanic activities also play a crucial role for enriching the water reservoirs with heavy metals $[3,4]$.Toxic heavy metals are considered one of the pollutants that have direct effect on man and animals. It is well known that heavy metals are toxic and they can damage nerves, liver and bones, and they can block functional groups of vital enzymes too. Metal ions such as $\mathrm{Cd}, \mathrm{Cr}, \mathrm{Co}, \mathrm{Cu}, \mathrm{Zn}$, $\mathrm{Pd}, \mathrm{Hg}, \mathrm{Ni}, \mathrm{Ag}$, and $\mathrm{Sr}$ and metalloids such as $\mathrm{Se}$, $\mathrm{As}$, and $\mathrm{Sb}$ are toxic if consumed beyond permissible limits.[5,6]Chromium is one of the toxic environmental and industrial pollutant. Chromium in particular has received attention due to its hazardous nature[2,7].Chromium compounds present in the effluents as a result of electroplating, metal finishing, magnetic tapes, wood preservation, leather tanning, pigments and chemical manufacturing industries.[8,9]This heavy metal occurs in the environment in two oxidation states: trivalent $\mathrm{Cr}$ (III) and hexavalent $\mathrm{Cr}(\mathrm{VI}) . \mathrm{Cr}(\mathrm{III})$ is considered as an essential trace nutrient for human, while $\mathrm{Cr}(\mathrm{VI})$ in turn is highly toxic $[10,11]$. Because of its mutagenic and carcinogenic properties, its intake may induce skin irritation lung cancer and kidney/liver damage.[12] It may also cause gastric pain, nausea, vomiting, severe diarrhea, and hemorrhage.[13,14] Therefore, removal of $\mathrm{Cr}(\mathrm{VI})$ from wastewater is essential before its disposal.The Conventional methods for removing dissolved heavy metal ions include chemical precipitation, chemical oxidation /reduction, filtration, ion exchange, electrochemical treatment and membrane technology.Most of them involve high capital costs with recurring expenses, which are not suitable for smallscale industries. Adsorption method is considered to be one of the 
preferable methods for the removal of heavy metal ions from aqueous solution due to its significant advantages such as low operational cost, wide applicability and creation of relatively low sludge.[15-20]

The present research article reports the removal of Chromium(VI) by adsorption on to low cost material Ficusracemosabark and Bombaxceiba bark based activated carbon.

\section{MATERIALS AND METHODS:}

All the chemicals used were of analytical or chemically pure grade. Distilled water was used throughout the investigation.

\section{PREPARATION OF ACTIVATED CARBON FROM THE FICUSRACEMOSA BARK(ACFRB) AND BOMBAXCEIBA BARK (ACBCB) :-}

Ficusracemosa bark and Bombaxceiba barkwas collected from the nearby local forest area and it was cut into small pieces. It was wash with distilled water and dried in sunlight to remove the moisture. Then it was treated with formaldehyde to avoid the release of color by bark into the aqueous solution during the adsorption process. The above treated bark was carbonized by slow heating over a wide range of temperature $\left(400-700^{\circ} \mathrm{C}\right)$ in the absence of air in a muffle furnace. The char obtained was subjected to thermal activation in the absence of air at elevated temperature $900 \circ \mathrm{C}$ and held at that temperature for $1 \frac{1}{2}$ hour. The adsorbent so obtained was ground and sieved through 200 mesh sieves. The dried sample was stored in airtight bottles for further use.[2,20,21]

\section{Preparation of stock solution:}

Concentrations of $\mathrm{Cr}(\mathrm{VI})$ ion in solutions were estimated calorimetrically applying standard methods.[22,23] Standard Cr(VI) solution was prepared by dissolving $0.2829 \mathrm{~g}$ of potassium dichromate crystals in distilled waterand making the volume up to $100 \mathrm{~cm}^{3}$. Exactly $50 \mathrm{~cm}^{3}$ of this solution was transferred into a $500 \mathrm{~cm}^{3}$ volumetricflask and made up using distilled water to get a solution containing $0.1 \mathrm{mg}$ of $\mathrm{Cr}(\mathrm{VI})$ ions per $\mathrm{cm}^{3}$. Solutions ofvarious required concentrations were prepared by diluting suitable aliquots of the above solution with distilled water.

\section{CHARACTERIZATION OF ACBCB:-} SEM STUDIES OF ACBCB:-

Fig. 1 shows the SEM image of ACBCB which is obtained using an accelerating voltage of $15 \mathrm{kV}$ at $\mathrm{x}$ 400 magnification. SEM micrographs clearly revealed that small pores are presents on the surface of activated carbon(ACBCB) accompanied with fibrous structure. It can also be noticed that the surface structure of $\mathrm{ACBCB}$ is irregular, which would have good capacity of this adsorbent for accumulation of metal ions easily.

\section{FTIR STUDIES OF ACBCB:-}

FTIR spectrum of ACBCB has shown in Fig.2. The band at $3300-3800 \mathrm{~cm}^{-1}$ is due to stretching vibrations of phenolic hydroxyl $(-\mathrm{OH})$ group. The peak at $2359 \mathrm{~cm}-1$ shows presence of bonded $-\mathrm{OH}$ groups involved in Hydrogen bonding. The peaks appeared at $1090.28,1216.02$ and $752.45 \mathrm{~cm}^{-1}$ are due to methylene bridge coupled with aromatic ring. A peak at $1503 \mathrm{~cm}-1$ may be ascribed to $\mathrm{N}-\mathrm{H}$ bending of secondary amide group. A sharp peak noticed at $1550.61 \mathrm{~cm}-1$ may be due to $\mathrm{C}=\mathrm{N}$ stretching vibration.

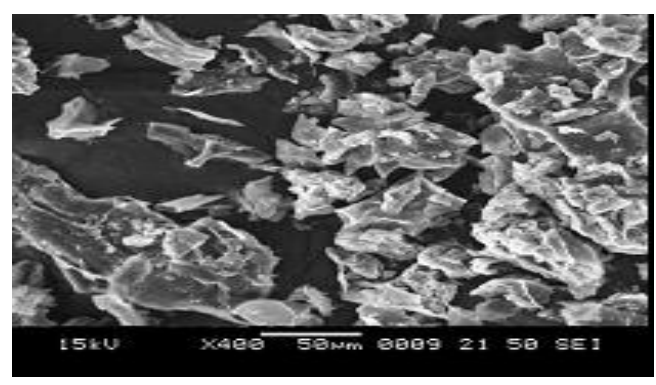

Fig. 1:- SEM of ACBCB

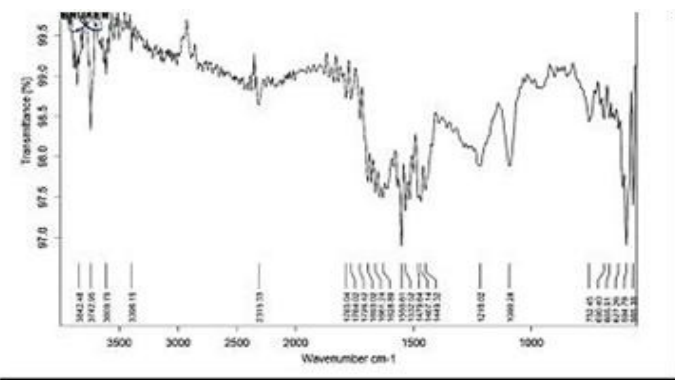

Fig 2:- FTIR Spectrum of ACBCB

CHARACTERIZATION OF ACFRB:SEM STUDIES OF ACFRB:-

Fig. 3 shows the SEM image of ACFRB.Micrograph is taken under magnification of $15 \mathrm{kV}$ at x500magnification. SEM micrograph of ACFRB shows that the surface is non-smoothy,with few cracks and lot of voids. The external surface is having quite irregular cavities and pores. The shape is irregular and the presence of voids on the surface of ACFRB, makes it excellent host for the molecules/metal ions accumulation on it.

\section{FTIR STUDIES OF ACBCB:-}

FTIR spectrum of ACFRB is presented in Fig 4. Appearance of band at region $3300 \mathrm{~cm}^{-1}$ is due to the stretching vibration of phenolic hydroxyl $(-\mathrm{OH})$ group. The peak $1631.43 \mathrm{~cm}^{-1}$ due to the stretching 
vibration of $\mathrm{C}=\mathrm{O}$ in Carboxylic acid group $(-\mathrm{COOH})$. The additional peak at 578 to $638 \mathrm{~cm}^{-1}$ can be assigned to bonding modes of aromatic compound.Another absorption band at $1195.33 \mathrm{~cm}$ 1 could be attributed to $\mathrm{C}-\mathrm{OH}$ stretching. The band at $1078.29 \mathrm{~cm}^{-1}$ corresponded to the $(\mathrm{C}-\mathrm{O}-\mathrm{C})$ asymmetric stretching vibration.The peaks appeared at 1440 and $1167 \mathrm{~cm}^{-1}$ are due to methylene bridges coupled with aromatic ring.A band at $1605 \mathrm{~cm}^{-1}$ is indicative of $\mathrm{C}=\mathrm{O}$ stretching in aldehyde or ketone in which hydrogen bonding is possible. The broad bands between $3000-3700 \mathrm{~cm}^{-1}$ indicate the presence of stretching vibrations of phenolic hydroxyl $(-\mathrm{OH})$ group.

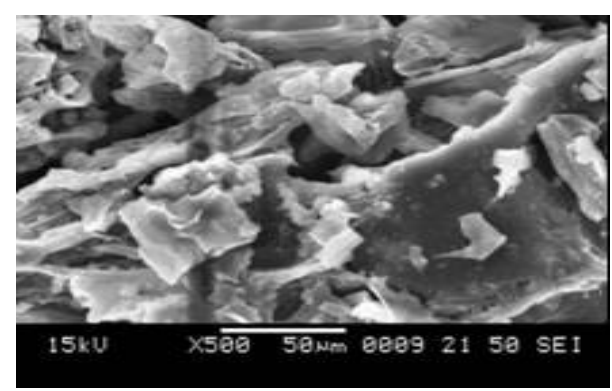

Fig. 3:- SEM of ACFRB

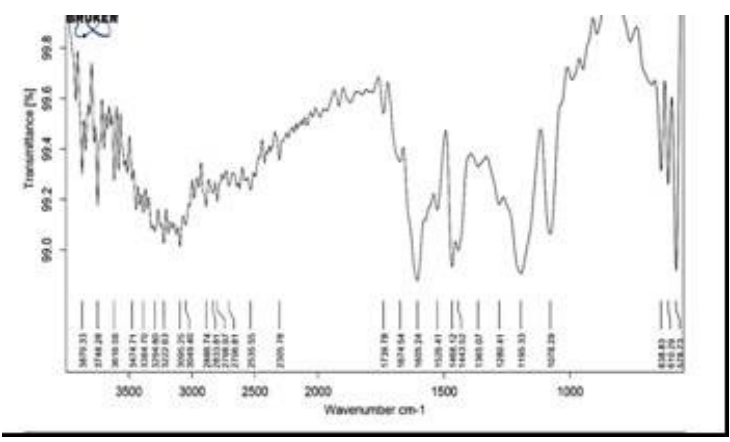

Fig 4:- FTIR Spectrum of ACFRB

\section{RESULTS AND DISCUSSION:}

\section{EFFECT OF CONTACT TIME ON ADSORPTION:-}

For a fixed concentration of heavy metals and a fixed adsorbent mass, the retention of heavy metals increased with increasing contact time before equilibrium is reached. It can be seen that $\mathrm{Cr}(\mathrm{VI})$ removal efficiency of activated carbon derived from the bark of Bombaxceiba(ACBCB) was greater in the initial stages then gradually increased upto $95.04 \%$ and remains almost constant, after optimum period of $100 \mathrm{~min}$. and from the Ficusracemosabark (ACFRB) increased up to $83.26 \%$, when contact time was increased from $10 \mathrm{~min}$ to $120 \mathrm{~min}$. Thus optimum contact time was found to be $120 \mathrm{~min}$

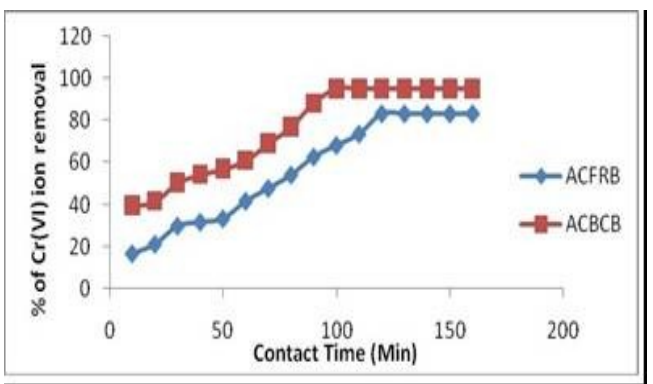

Fig. 5: Effect of contact time on $\mathrm{Cr}(\mathrm{VI})$ ion removal by activated carbon derived from Bombaxceiba bark (ACBCB) andFicusrecemesa bark (ACFRB)

\section{EFFECT OF PH ON ADSORPTION:-}

Effect of $\mathrm{pH}$ on $\mathrm{Cr}(\mathrm{VI})$ ion adsorption using activated carbon derived from the bark of Bombaxceiba(ACBCB) and Ficusracemosa bark (ACFRB)has been studied in the $\mathrm{pH}$ range 1 to 10 and presented in Fig.6. The $\mathrm{pH}$ of the aqueous solution is one of the key factors that control the adsorption process of $\mathrm{Cr}(\mathrm{VI})$ ion. $\mathrm{Cr}(\mathrm{VI})$ ion removal efficiency was found $96.8 \%$ at $\mathrm{pH} 5$ for $\mathrm{ACBCB}$ and $89.5 \%$ at $\mathrm{pH} 5$ for ACFRB. Maximum adsorption of $\mathrm{Cr}(\mathrm{VI})$ ion was observed at the acidic $\mathrm{pH}$. This is because at lower $\mathrm{pH}$ there is increase in concentration of $\mathrm{H}^{+}$ions on the carbon surface.

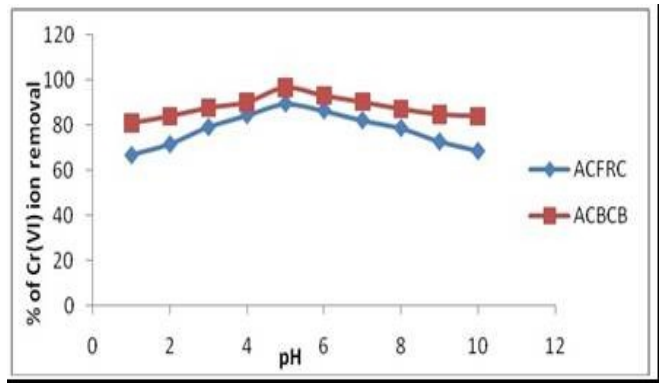

Fig. 6: Effect of $\mathrm{pH}$ on $\mathrm{Cr}(\mathrm{VI})$ ion removal by activated carbon

derived fromBombaxceiba bark (ACBCB) andFicusrecemesabark(ACFRB)

\section{EFFECT OF ADSORBENT DOSAGE:-}

The effect of adsorbent doses on percent removal of $\mathrm{Cr}(\mathrm{VI})$ in the range 1 to $10 \mathrm{gm}$ is represented in Fig.7. The obtained results reveal that the percentage removal of $\mathrm{Cr}(\mathrm{VI})$ ions increased with an increase in the adsorbents dose but after certain adsorbent dose it becomes constant and it is treated as an optimum adsorbent dose. Maximum adsorption was observed at $6 \mathrm{gm} / \mathrm{lit}$ i.e. $97.74 \%$ for $\mathrm{ACBCB}$. Thus $6 \mathrm{gm} /$ lit is optimum adsorbent dose for 
$\mathrm{ACBCB}$ adsorbent and for ACFRB it was found that $92.74 \%$ at $7 \mathrm{gm} /$ lit.

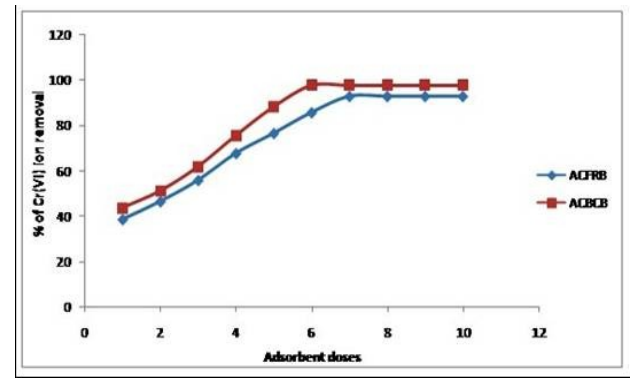

Fig.7: Effect of adsorbent dose on $\mathrm{Cr}(\mathrm{VI})$ ion removal by activated carbon derived

fromBombaxceiba bark (ACBCB) andFicusrecemesa bark(ACFRB)

\section{ADSORPTION ISOTHERM:}

\section{LANGMUIR ADSORPTION ISOTHERM:}

The results obtained from Langmuir model for the removal of $\mathrm{Cr}(\mathrm{VI})$ ion by $\mathrm{ACBCB}$ and ACFRB has been represented in Fig. 8 and 9. The adsorption efficiency "Qm" value for $\mathrm{Cr}(\mathrm{VI})$ ion was found to be 11.061 and $11.286 \mathrm{mg} / \mathrm{g}$ while value of "b" was 0.1492 and 0.1887 respectively. The lower values of $b$ (less than one) implies an excellent the affinity between solute and sorbent sites. The value of square of the correlation coefficient $\left(\mathrm{R}^{2}\right)$ is found to be 0.9782 and 0.9903 for $\mathrm{Cr}(\mathrm{VI})$, which show the best fitting of equilibrium data. The value of RL lies between 0 and 1 for favourable adsorption, while RL>1 represents favourable adsorption and $\mathrm{RL}=1$ represents linear adsorption while the adsorption process is irreversible if $R L=0$. The dimensionless parameter RL values lies between 0.160 and 0.178 is consistent with the requirement for favourable adsorption.

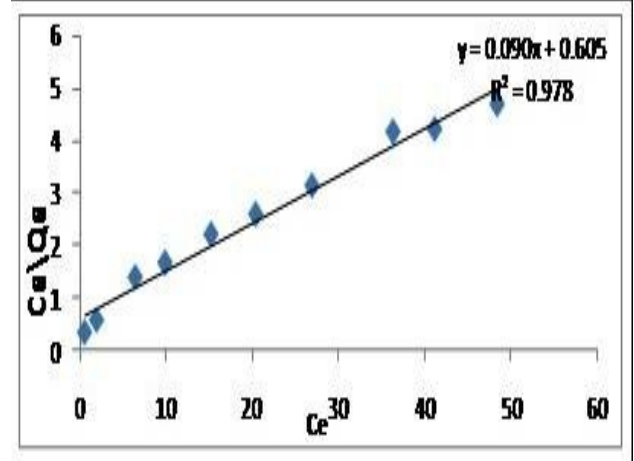

Fig. 8: Langmuir isotherm for the adsorption of $\mathrm{Cr}(\mathrm{VI})$ ion on activated carbon derived from Bombaxceiba bark (ACBCB)

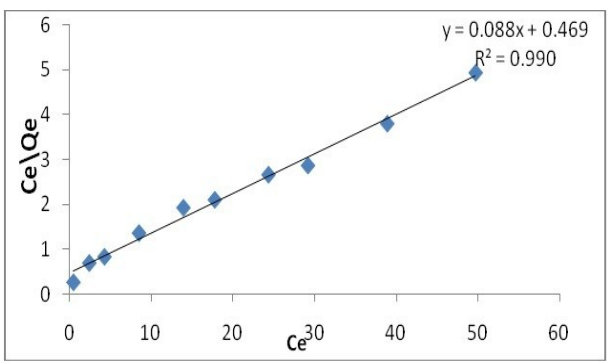

Fig. 9: Langmuir isotherm for the adsorption of $\mathrm{Cr}(\mathrm{VI})$ ion on activated carbon derived from Ficusracemosa bark

\section{FREUNDLICH ADSORPTION ISOTHERM:}

The plot of $\log \mathrm{Ce}$ versus log Qe for $\mathrm{Cr}(\mathrm{VI})$ is presented in Fig. 10 and 11 which show linear curve with a slope of $1 / \mathrm{n}$ and intercept of $\log \mathrm{Kf}$ and hence the adsorption process obeys Freundlich adsorption isotherms. Freundlich constants " $n$ " for $\mathrm{Cr}(\mathrm{VI})$ were found to be 2.686 and $2.504 \mathrm{mg} / \mathrm{g}$ and "Kf" 1.484 and $1.508 \mathrm{mg} / \mathrm{g}$ for ACBCB and ACFRB respectively. The square of the correlation coefficient $\left(\mathrm{R}^{2}\right)$ value was found to be 0.9856 and 0.9896 for $\mathrm{Cr}(\mathrm{VI})$ which shows well-fitting of the Freundlich isotherm. The " $n$ " value are in between 1 to 10 which indicate the favourable adsorption of $\mathrm{Cr}(\mathrm{VI})$ on $\mathrm{ACBCB}$ and ACFRB

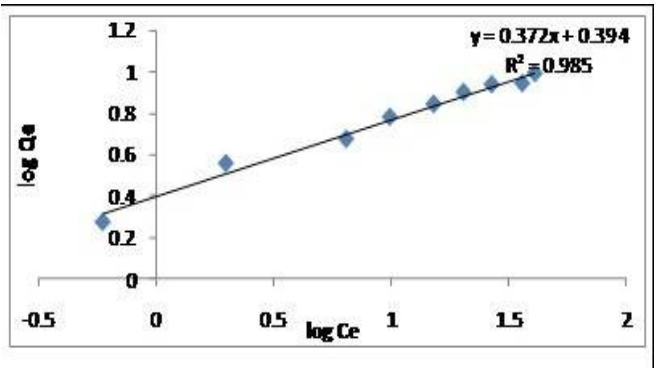

Fig.10: Freundlich isotherm for the adsorption of $\mathrm{Cd}(\mathrm{II})$ ion on activated carbon derived from Bombaxceiba bark (ACBCB)

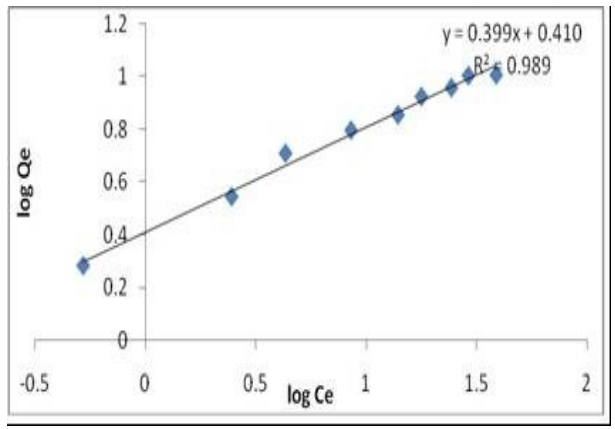

Fig.11: Freundlich isotherm for the adsorption of $\mathrm{Cd}(\mathrm{II})$ ion on activated carbon derived from Ficusracemosa bark 


\section{CONCLUSION:}

Activated carbon was successfully generated from naturally available raw material that is the Ficusracemosabark andBombaxceiba barkwhich is abbreviated as "ACFRB" and "ACBCB". The ACBCB was found to be most effective for $\mathrm{Cr}(\mathrm{VI})$ ion removal as compare to ACFRB. $\mathrm{Cr}(\mathrm{VI})$ was removed from aqueous solution by using $\mathrm{ACBCB}$, at $\mathrm{pH} 5,96.8 \%$ of $\mathrm{Cr}(\mathrm{VI})$ was removed from aqueous solution and adsorption was found to be $\mathrm{pH}$ dependent. Maximum $\mathrm{Cr}(\mathrm{VI})$ removal is $97.74 \%$ for $6 \mathrm{gm} / \mathrm{lit}$ optimum adsorbent dose at $100 \mathrm{~min}$ of optimum contact time. The experimental data for the adsorption process were well fitted by the Langmuir adsorption isotherm model and Freundlich adsorption model too. Thus the newly generated Bombaxceiba barkbased activated carbon (ACBCB) reported in this research article has been proved to be an excellent eco-friendly and low-cost adsorbent material which can be successfully used for elimination of $\mathrm{Cr}(\mathrm{VI})$ from contaminated water.

\section{ACKNOWLEDGEMENTS:}

Authors are thankful to the Principal and Head of the Chemistry Department, Priyadarshini College of Engineering, Nagpur, India for providing the necessary laboratory and library facilities.

\section{REFERENCE}

1. Swathi A Patel "Removal of Heavy Metal Using Natural Adsorbents",(2012)M.TechThesis

2. D.K.Donadkar, P.K.Rahangdale, K.Gour,(2017), International Journal of Advanced Research, vol.5(6), 204-209

3. Jonathan Y., (2010) Am. J. Appl. Sci. $7(2), 153$.

4. Kamruzzaman B.Y. and M.C., (2009), Am. J, App Sci.6(7), 1418.

5. S. Arivoli, M. Hema, M. Karuppaiah, and S. Saravanan (2008), E- Journal of Chemistry, vol. 5 , no. 4, pp. 820-831,

6. K. Mohanty, M. Jha, B. C. Meikap, and M. N. Biswas(2005), Chemical Engineering Science,vol. 60, no. 11, pp. 3049-3059,

7. P.V.Hemalatha, P.V.V.PrasadaRao "Adsorption Batch Studies on Calcined Brick Powder in Removing Chromium and Nickel Ions".IJARCS.vol 1, pp 14-21,2014.

8. V. K. Gupta, A. Rastogi, and A. Nayak, "Adsorption studies on the removal of hexavalent chromium from aqueous solution using a low cost fertilizer industry waste material," Journal of Colloid and Interface Science, vol. 342, no. 1, pp. 135-141, 2010.

9. W.-Q. Wang, M.-Y. Li, and Q.-X. Zeng, "Thermodynamics of $\mathrm{Cr}(\mathrm{VI})$ adsorption on strong alkaline anion exchange fiber,"
Transactions of Nonferrous Metals Society of China, vol. 22, no. 11, pp. 2831-2839, 2012.

10. R. Dobrowolski and M. Otto, "Study of chromium(VI) adsorption onto modified activated carbons with respect to analytical application," Adsorption, vol. 16, no. 4-5, pp. 279-286, 2010.

11. J. O. Nriagu and E. Nieboer, "Chromium," in Natural and Human Environment, Wiley, New York, NY, USA, 1988.

12. A. Mansri, K. I. Benabadji, J. Desbrières, and J. François, "Chromium removal using modified poly(4-vinylpyridinium) bentonite salts," Desalination, vol. 245, no. 1-3, pp. 95-107, 2009.

13. F. Gholami, A. H.Mahvi, Gh. A.Omrani, S.Nazmara, A. Ghasri, Iran. J. Environ. Health. Sci. Eng. 2006, 3, 97- 102.

14. S. Arivoli, M. Hema, M. Karuppaiah, and S. Saravanan, E- Journal of Chemistry, 2008, vol. 5, no. 4, pp. 820-831,

15. P.Venkateswarlu, M. VenkataRatnam, D. SubbaRao and M. VenkateswaraRao, International Journal of Physical Sciences, 2007, Vol. 2 (8), pp. 188-195.

16. Ali Shafaghat, FarshidSalimi, Mahdi Valiei, JaberSalehzadeh and MasoudShafaghat, African Journal of Biotechnology, 2012, Vol. $11(4)$, pp. 852-855.

17. AlemayehuAbebawMengistie, T. Siva Rao, A. V. PrasadaRao, Global Journal of Science Frontier Research Chemistry, 2012, Volume 12 Issue 1 Version 1.0.

18. S. L Pandharipande, UmeshDhomane, PradipSuryawanshi, NitinDorlikar, International Journal of Advanced Engineering Research and Studies (IJAERS), 2012, Vol. I, Issue III, pp 214-216.

19. S. L. Pandharipade, YogeshMoharkar, Raj Thakur,(2012), International Journal of Engineering Research and Applications (IJERA), Vol. 2, Issue4, pp.1337-1341.

20. D.K.Donadkar,

P.K.Rahangdale, K.Gour,(2016),Der PharmaChemica, 8(10):230-235.

21. N.D.Vilayatkar, P.K. Rahangdale, D.K. Donadkar (2016), International Journal of Advanced Research, Vol 4(5), 1360-1364 1360.

22. Cumming and Kay. (1948) Quantitative chemical Analysis 10th Edn.

23. AI. Vogel Vogel's textbook of quantitative inorganic analysis, : Prentice Hall, 1978, 4th edn. ELBS. 